analysis of the denationalization ("ethnocide") of the Ukrainian population, largely, though not wholly, through linguistic Russification. The second and more interesting part consists of an impressive discussion of the purge of Ukrainian party cadres and intelligentsia during the early 1970 s and of the repression of Ukrainian language, culture, and religion under the Brezhnev regime. Appended are a number of poems by "Sahaydak."

Doubts about the authenticity of this unusual document have been expressed in various forums, and there are some anomalies that require explanation before this issue of Visnyk is accepted, without reservation, as having originated in Soviet Ukraine. For example, the Ukrainian original employs language (the words sovetskii, KGB, $v$ Ukraine, references to Russian "colonialism," and so forth) that are more characteristic of émigré than of Soviet Ukrainian writing. In addition, the Moscow-based Chronicle of Current Events has published reviews of all issues of the Visnyk except this one. At our most sanguine, we must conclude that the document is far outside the mainstream of Ukrainian underground writing.

KenNeth C. FARMer

Marquette University

PŘISPĚVKY K DËJINÁM ČESKO-RUSKYCH KULTURNICH STYKU゚/3. Prague: Lidové nakladatelství, 1976. 171 pp. Kčs. 19.

NÁSTIN VZTAHŮ MEZI ČSKOSLOVENSKOU A SOVETSKOU VËDOU: ZÁKLADNÍ RYSY VZTAHƯ V RAMCI AKADEMIf OD 18. STOLETI DO SOUČASNOSTI. By K. Herman et al. Prague: Academia, 1975. 114 pp. Kčs. 11, paper.

CESKOSLOVENSKO-SOVĚTSKE VZTAHY JAKO FAKTOR MEZINÁRODNI POLITIKY, 1917-1970. Compiled and edited by František Hejl. Prague: Academia, 1975. 310 pp. Kčs. 38.

The three volumes under review are symposia consisting of contributions by a number of Czech, Slovak, and Soviet authors. The volume edited by Hejl is written in Czech and Slovak, and the other two provide summaries in Czech of papers in Russian and vice versa.

Př́spěvky is a miscellany of readings, of varying lengths, on rather unrelated topics, such as a four-page reminiscence about the sojourn of Peter the Great in Karlsbad in 1711 and 1712, a review of Czech themes in nineteenth-century Russian poetry, an article on how a Czech nineteenth-century composer wrote music for one of Pushkin's poems, and a brief account about the Slavic library in Prague. Almost half of the volume, however, has little to do with Czech-Russian cultural relations (supposedly the subject of the book) ; instead, it is devoted to a critical evaluation of memoirs about the October Revolution and the Russian civil war written by Czechoslovak legionnaires in 1919-38.

Nástin is actually a sort of Festschrift published to commemorate the two-hundredfiftieth anniversary of the fuunding of the first Russian Academy of Sciences (Petersburg Imperial Academy of Sciences), which was subsequently converted into the Academy of Sciences of the USSR. Although the book traces the development and the activities of the academy, the volume's primary concern is the contacts that developed between the academy and Czech and Slovak scientists, writers, and cultural and scientific institutions, including the Czech Academy of Sciences (founded in 1890). The authors' treatment of the subject for the period prior to 1917 appears to be devoid 
of the ideological bias that usually mars studies by orthodox Communist historians. But when they begin to tackle the more recent period, their slanted ideological orientation becomes all too apparent. "Victorious February 1948" is portrayed as having ushered in a bright future for the development of Czechoslovak science and the Soviet Academy of Sciences is presented as a model to be emulated: for example, in 1968 "ideologically unstable individuals began to succumb to the temptations of inimical bourgeois ideology," "bearers of right-wing opportunism and revisionist tendencies" set out to denigrate the value of the rich Soviet experience and even some members of the presidium of the academy "retreated from the positions of proletarian internationalism"; but in 1969 "discipline was fully restored" and all was well again.

Československo-sovětské vztahy is a collection of twenty-five papers which were presented at a conference of the commission of Czechoslovak and Soviet historians held in Prague in October 1973 on the occasion of the twentieth anniversary of the conclusion of the Czechoslovak-Soviet Treaty of Friendship, Mutual Assistance, and Postwar Cooperation. Arranged in chronological order, the papers cover various aspects of Soviet-Czechoslovak relations from the time of the October Revolution until the conclusion of the new Czechoslovak-Soviet Treaty of Friendship, Cooperation, and Mutual Assistance in 1970. Unfortunately, the contributors merely paraphrase standard Soviet theses and interpretations relating to topics such as the October Revolution and its allegged significance for Czechoslovakia's independence; President Benešs decision not to go to war at the time of Munich in spite of asserted Soviet willingness to help and his wartime endeavors to "isolate the Soviet Union from Europe"; the "longing" of the people of Subcarpathian Ukraine to join the Soviet Ukraine; and the fraternal "international aid of five socialist countries," given to Czechoslovakia in 1968.

Taken together, the three books constitute a telling testimony of how far the pendulum has swung from the promising days of the 1968 Czechoslovak Spring back to the stifling orthodoxy of the Stalin era. They also corroborate the assertions of the signatories of Charter 77 about the Husák regime's disregard for freedom of expression, press, and scientific research.

EDWARD TABORSKY

University of Texas, Austin

\section{THEORETISCHE GRUNDLAGEN UND PRAKTISCHE ENTWICKLUNG LANDWIRTSCHAFTLICHER BETRIEBSGRÖSSEN IN DER TSCHE- CHOSLOWAKEI. By Vladislav Bajaja. Osteuropastudien der Hochschulen des Landes Hessen, series 1. Giessener Abhandlungen zur Agrar- und Wirtschaftsfor- schung des europäischen Ostens, vol. 69. Berlin: Duncker \& Humblot in Kommis- sion, 1975. 324 pp. Paper.}

In this very detailed and interesting book the author has tackled important theoretical and practical problems concerning optimum farm size in socialized Czechoslovak agriculture. His presentation of the complex phenomena of movements toward large-scale agriculture-coupled with horizontal and vertical integration-is both systematic and lucid.

The question of farm size in Czechoslovakia-as well as in all other East European countries and the USSR - has been a central economic and political issue since World War I, when most of the farms throughout the region were too small for mechanization or for providing their owners with even a modest livelihood. A series of agrarian reforms in Czechoslovakia and other East European countries in the interwar period attempted to increase the average size of agricultural holdings in order to improve 